\title{
EFFECT OF MECHANICAL PROCESSING OF MINCED MEAT ON THE CHANGE OF YIELD STRESS
}

\author{
BOLAT KABULOV ${ }^{1}$, AYAULYM MUSTAFAYEVA ${ }^{2}$, NAZIRA KUDERINOVA ${ }^{3}$, SAMAT KASSYMOV ${ }^{4}$, \\ MARS KHAYRULLIN ${ }^{5}$, ARTUR PAVLOV ${ }^{6}$, VLADIMIR ERMOLAEV ${ }^{7}$, ANASTASIA KUZMINA $^{8}$ \& \\ ALLA VOROBEVA ${ }^{9}$ \\ ${ }^{1,3,4}$ Shakarim State University of Semey, Semey, Kazakhstan \\ ${ }^{2}$ Saken Seifullin Kazakh Agrotechnical University, Nur-Sultan, Kazakhstan
}

${ }^{5,8,9}$ K. G. Razumovsky Moscow State University of technologies and management (the First Cossack University), Moscow, Russia

${ }^{6}$ Bashkir State Agrarian University, Ufa, Russia

${ }^{7}$ T. F. Gorbachev Kuzbass State Technical University, Kemerovo, Russia

\begin{abstract}
In this paper, the mechanical processing of minced meat and its effect on structural-mechanical properties is presented. The constructed experimental mincer consists of cutter-mixer and filling machine. Angular rate of the knife shaft varied within $52.3 ; 167.5 ; 293 ; 418.7 s-1$. The angular rate of the mixer screw varied within 2.09; 4.19; 6.28; $8.37 \mathrm{~s}$-1. The duration of processing of meat in the experimental equipment was 180, 360, 540 and $720 \mathrm{~s}$. The yield stress of minced meat during the mechanical processing depending on duration of process gradually increased from $180 \mathrm{~s}$ to $540 \mathrm{~s}$ and then gradually decreased. Equations are proposed for calculating the extreme values of yield stress depending on the mechanical processing regime.

KEY WORDS: Meat Processing, Grinding, Mixing, Forming, Yield Stress, Angular Rate, Screw \& Knife
\end{abstract}

Received: Aug 15, 2019; Accepted: Aug 30, 2019; Published: Sep 14, 2019; Paper Id.: IJMPERDOCT201928

\section{INTRODUCTION}

Meat-processing enterprises produce various types of sausages and meat products. Increasing the volume and range of sausage products is the first order of business. In the new economic conditions of the market, the number of small meat-processing enterprises is growing rapidly. These small enterprises need new equipment, technology and methods for preserving the quality of sausage product. One of the ways to improve the quality of sausages is to further improve the mechanical processing of minced meat (Antipov et al., 2001; Titova et al., 2018).

To solve this problem, it is necessary to intensify the processes of fine grinding, mixing and molding of minced meat with their combination in one unit and to develop rational modes of these processes. Modern stringent requirements for energy saving, environmental protection, saving production space and reducing maintenance personnel bring the problem of creating mini-equipment with combined technological processes to one of the top priorities of food engineering (Muratzhankyzy et al., 2018; Solovyov \& Lisitsyn, 2005).

Mechanical processing of meat, including the processes of fine grinding, mixing and forming minced meat, occupies the main place in the technological scheme of sausages production. The feature of these processes is that the quality of the sausages is predetermined by the values of the properties achieved during processing (Kakimov et 
al., 2017; Mustafayeva et al., 2016).

The basic factors of the influence of rheological parameters and the duration of grinding on the quality and yield of finished meat products are determined (Kosoj, Malyshev, \& Judina, 2005). However, in the processes of complex mechanical processing, the stuffing is additionally subjected to mechanical stress in order to evenly distribute the components throughout the entire volume of the cutter or mixer. During molding, a change in the structural and mechanical properties and other characteristics of minced meat also occurs. It is established that using of rheological methods for controlling and monitoring the mechanical processing of minced meat is the reliable method for obtaining high quality food product (Kakimov et al., 2015).

The results of conducted research on the effect of processing time on the properties of minced meat are related only to a particular mechanical process, as grinding, forming or mixing (Pelenko et al., 2008). But there is lack of results on studying the effect combined processes on quality of minced meat.

At present time, in the small meat-processing enterprises and mini-sausage shops the processes of grinding, mixing and filling are performed separately using specific operating equipment. The existing equipment, mainly intended for large enterprises, occupies large production areas, consumes a huge amount of electricity and allows to perform only one technological operation, as a result, high product lost occurred during transportation from one equipment to another.

Based on the above analysis, we can conclude that one of the possible ways to solve the problems facing small meatprocessing enterprises is the development and creation of multi-operational technological mini-machines of low productivity.

The purpose of this work is to study the effect of mechanical processing (cutting, mixing, filling) of minced meat on the changing of the yield stress and density of minced meat.

\section{MATERIALS AND METHODS}

To study the processes of complex mechanical processing of the minced meat, the experimental mincer equipment was constructed (Figures 1; Tuleuov et al., 2003). Experimental mincer equipment consists of cutter-mixer 3, filling machine 5 and accessory drives 6, 8, 10 (Figure 1). Its design allows to combine the processes of fine grinding, mixing and filling of minced meat in one unit (Kakimov, Tuleuov, \& Kabulov, 2003). Experimental mincer equipment has a small machine capacity with a process control system for variation of rotation speeds of the blade shaft and screw. This equipment can be used for fine grinding of chopped meat, mixing with ingredients and filling into casings. Also, it can be used for production of minced meat for sausages and other meat products.

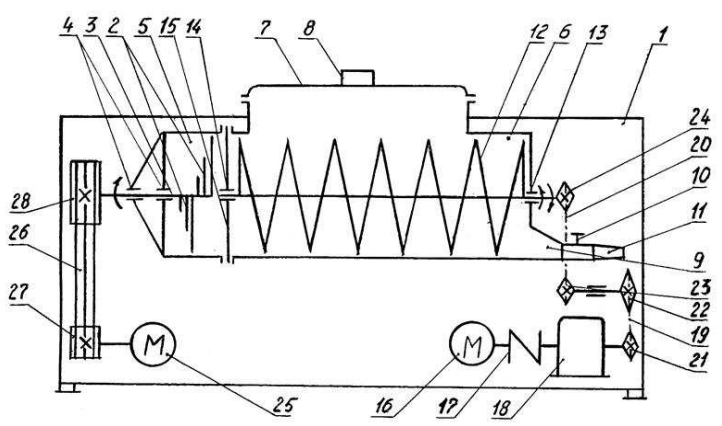

Figure 1: Kinematic Scheme of The Experimental Mincer Equipment. 
1-base; 2-knives; 3-primary shaft; 4, 13, 14-bearing supports; 5-housing; 6-vat; 7-coverplate; 8-handle; 9-outlet nozzle; 10-faucet; 11-tube; 12-screw; 15-grid; 16, 25-motors; 17-socket joint; 18-step-down gear; 19, 20-chain wheel gear; 21, 22, 23, 24-turnstile; 26-pulley-belt arrangement; 27, 28-pulley wheel.

Table 1: Technical Characteristic of the Experimental Mincer Equipment

\begin{tabular}{|c|c|}
\hline Equipment capacity, kg/h & 100 \\
\hline Vat volume, $\mathrm{m}^{3}(\mathrm{l})$ & $0,02(20)$ \\
\hline $\begin{array}{l}\text { Cutter: } \\
\text { power of motor, kilowatt } \\
\text { number of revolutions of knives, } \min ^{-1}\end{array}$ & $\begin{array}{c}3 \\
500 / 1600 / 2800 / 4000\end{array}$ \\
\hline $\begin{array}{l}\text { Mixer: } \\
\text { power of motor, kilowatt } \\
\text { number of revolutions of mixer screw, } \min ^{-1}\end{array}$ & $\begin{array}{c}0,8 \\
20 / 40 / 60 / 80\end{array}$ \\
\hline $\begin{array}{l}\text { Filler: } \\
\text { power of motor, kilowatt } \\
\text { number of revolutions of screw, } \min ^{-1}\end{array}$ & $\begin{array}{l}0,37 \\
500\end{array}$ \\
\hline \multicolumn{2}{|l|}{ Dimensional specifications, $\mathrm{mm}$ : } \\
\hline Length & 1050 \\
\hline Width & 700 \\
\hline Height & 940 \\
\hline Weight, kg & 112 \\
\hline Manning level, man & 1 \\
\hline
\end{tabular}

The minced meat of "Doctorskaya" sausage was selected for experimental studies. This type of minced meat is widely used for production of sausages in Kazakhstan. The minced meat contains beef, pork and fat (Lavrova \& Krylov, 1975).

The meat was grinded on a meat chopper using the plate with the holes of $3 \mathrm{~mm}$. Then $10 \mathrm{~kg}$ grinded meat was laid into the hopper of the experimental mincer equipment. After that the cooled brine (50\% from the total amount) was added and mixed for $0.5-1 \mathrm{~min}$, then pork, spices and the rest of the brine were added and mixed. Samples were taken for every 120 seconds of mechanical processing. Angular rate of the knife shaft varied within 52.3; $167.5 ; 293 ; 418.7 \mathrm{~s}^{-1}$. The angular rate of the mixer screw varied within $2.09 ; 4.19 ; 6.28 ; 8.37 \mathrm{~s}^{-1}$ by changing the interchangeable pulleys.

The change in structural and mechanical properties (yield stress, plastic viscosity, and density) of minced meat from the duration of mechanical processing, angular rate of the blade shaft and mixer screw was determined.

\section{RESULTS AND DISCUSSIONS}

We studied the effect of different mode of mechanical processing of minced meat on yield stress behavior of minced meat. The early period of minced meat processing is up to $180 \mathrm{~s}$, which is described by the decrease in the values of structuralmechanical properties. The processing of meat in the meat mincer machine can be divided into three stages according to yield stress changing (Table 2).

During the experiments the duration of processing of meat in the meat mincer were 180, 360, 540 and $720 \mathrm{~s}$ (Figure 2). 
Table 2: The Values of Yield Stress, Plastic Viscosity and Density of Minced Sausage at the Angular Rate of Mixing Screw $2.09 \mathrm{~s}^{-1}$, Depending on Moisture, Fat, Water Content, Duration of Mechanical Processing and Angular Rate of a Knife Shaft

\begin{tabular}{|c|c|c|c|c|c|c|c|c|}
\hline 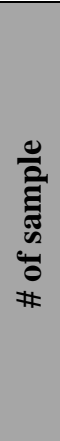 & 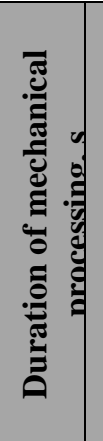 & 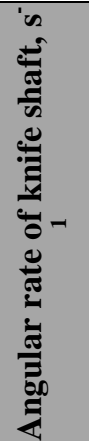 & 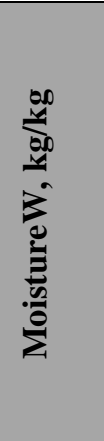 & 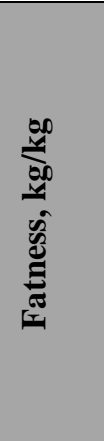 & 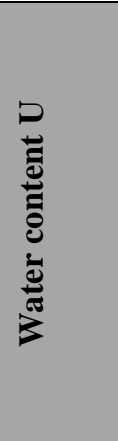 & 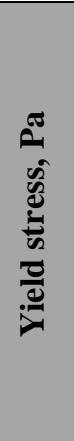 & 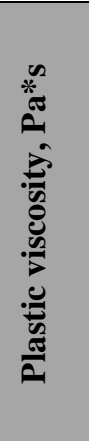 & 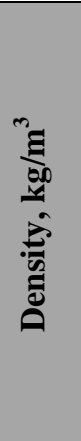 \\
\hline 1 & $\begin{array}{l}180 \\
360 \\
540 \\
720\end{array}$ & $\begin{array}{l}52.3 \\
- \\
- \\
-\end{array}$ & $\begin{array}{l}0.770 \\
0.794 \\
0.793 \\
0.803\end{array}$ & $\begin{array}{l}0.102 \\
0.081 \\
0.086 \\
0.081\end{array}$ & $\begin{array}{l}3.344 \\
3.8614 \\
3.8286 \\
4.0906\end{array}$ & $\begin{array}{l}680 \\
750 \\
820 \\
840\end{array}$ & $\begin{array}{l}7.4 \\
6.7 \\
6.35 \\
7.25\end{array}$ & $\begin{array}{l}1095 \\
1084 \\
1072 \\
1067\end{array}$ \\
\hline 2 & $\begin{array}{l}180 \\
360 \\
540 \\
720\end{array}$ & $\begin{array}{l}167.5 \\
- \\
- \\
-\end{array}$ & $\begin{array}{l}0.758 \\
0.762 \\
0.783 \\
0.803\end{array}$ & $\begin{array}{l}0.101 \\
0.108 \\
0.096 \\
0.071\end{array}$ & $\begin{array}{l}3.1322 \\
3.1946 \\
3.6062 \\
4.0487\end{array}$ & $\begin{array}{l}600 \\
660 \\
710 \\
750\end{array}$ & $\begin{array}{l}6.67 \\
6.23 \\
6.05 \\
6.3\end{array}$ & $\begin{array}{l}1093 \\
1081 \\
1073 \\
1065\end{array}$ \\
\hline 3 & $\begin{array}{l}180 \\
360 \\
540 \\
720 \\
\end{array}$ & $\begin{array}{l}293 \\
- \\
- \\
- \\
\end{array}$ & $\begin{array}{l}0.731 \\
0.753 \\
0.774 \\
0.763 \\
\end{array}$ & $\begin{array}{l}0.124 \\
0.110 \\
0.103 \\
0.104\end{array}$ & $\begin{array}{l}2.7188 \\
3.0469 \\
3.4209 \\
3.2158\end{array}$ & $\begin{array}{l}540 \\
610 \\
680 \\
690\end{array}$ & $\begin{array}{l}6.43 \\
6.15 \\
6.02 \\
6.25\end{array}$ & $\begin{array}{l}1088 \\
1079 \\
1072 \\
1065\end{array}$ \\
\hline 4 & $\begin{array}{l}180 \\
360 \\
540 \\
720\end{array}$ & $\begin{array}{l}418.7 \\
- \\
- \\
-\end{array}$ & $\begin{array}{l}0.713 \\
0.738 \\
0.762 \\
0.753\end{array}$ & $\begin{array}{l}0.122 \\
0.118 \\
0.108 \\
0.110\end{array}$ & $\begin{array}{l}2.488 \\
2.8139 \\
3.1946 \\
3.0429\end{array}$ & $\begin{array}{l}520 \\
580 \\
750 \\
760\end{array}$ & $\begin{array}{l}6.32 \\
5.97 \\
5.92 \\
6.17\end{array}$ & $\begin{array}{l}1086 \\
1077 \\
1071 \\
1063\end{array}$ \\
\hline
\end{tabular}

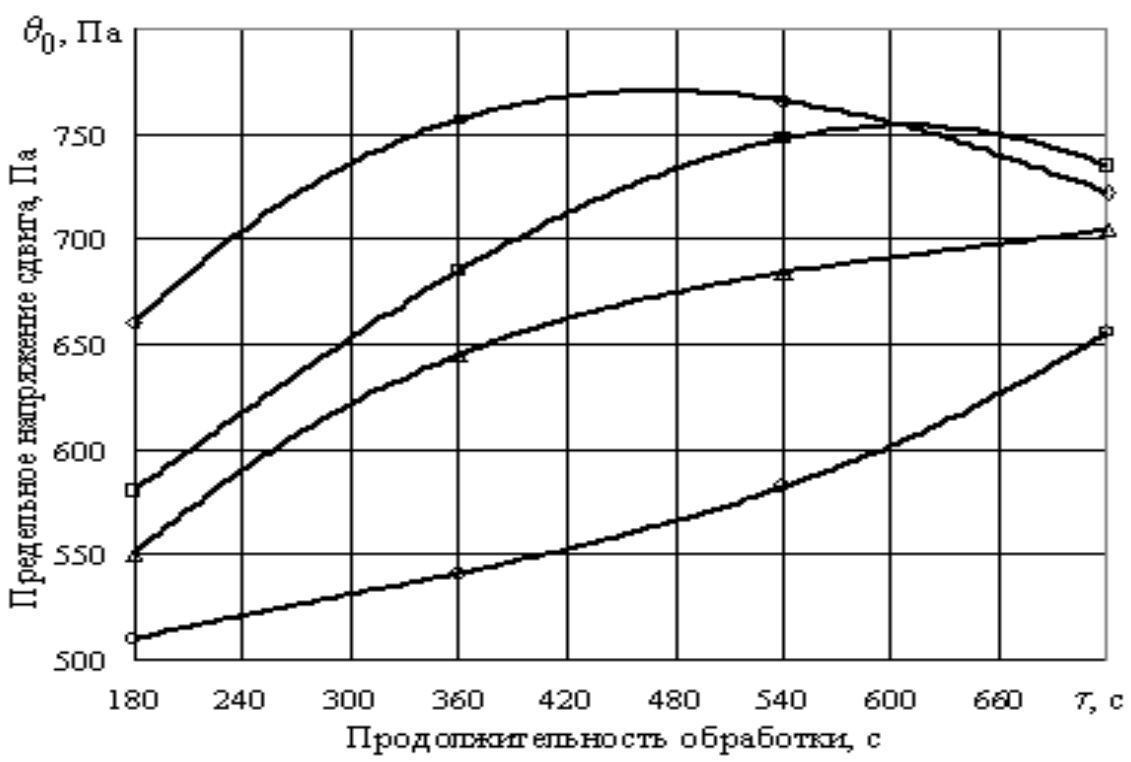

Figure 2: Change in Yield Stress of Minced Meat with Angular Rate of Knife Shaft $\boldsymbol{\Omega}_{\mathrm{m}}=\mathbf{2 , 0 9 \mathrm { s } ^ { - 1 }}$

$\mathbf{O}-\omega_{K}=52.3 \mathrm{~s}^{-1} ; \Delta-\omega_{\kappa}=167.5 \mathrm{~s}^{-1} ; \diamond-\omega_{K}=293 \mathrm{~s}^{-1} ; \square-\omega_{K}=418.7 \mathrm{~s}^{-1}$ 
In the first period of processing up to $360 \mathrm{~s}$, the value of the yield stress increased, due to the increase of the bounding surface and stronger binding of moisture with proteins and muscle fibers of minced meat. Intensive and fine cutting of meat particles lead to increasing of the total surface, and moisture from the free condition passed into surfacerelated (Zinina et al., 2018). During this period, the effective viscosity at a single value of the rate increased and reached a maximum value, and the plastic viscosity and water loss during the heat treatment decreased to the minimum values. The formation of the primary structure of minced meat was finished.

At the second stage of mechanical processing up to $540 \mathrm{~s}$ the muscle tissue of minced meat become more spread and the free water of meat strongly bond with meat substances. The temperature of the mass is constantly rising, the number of the smallest particles is increased and fat emulsified with water and protein of meat, which lead to secondary structure formation of minced meat. The yield stress reached maximum values and then gradually decreasing.

In the third stage up to $720 \mathrm{~s}$, the minced meat structure and consistency was hardened. Yield stress increased to some maximum. At the same time, there was an increase of fat droplets, further aeration of the whole mass of minced meat. When the fat droplets merged, the protein fraction probably retained moisture more firmly, strengthening the structure (Kakimov, Tuleuov, \& Kabulov, 2003).

Table 3: The Values of Yield Stress, Plastic Viscosity and Density of Minced Sausage at the Angular Rate of Mixing Screw 4.19 $\mathrm{s}^{-1}$, Depending on Moisture, Fat, Water Content, Duration of Mechanical Processing and Angular Rate of a Knife Shaft

\begin{tabular}{|c|c|c|c|c|c|c|c|c|}
\hline 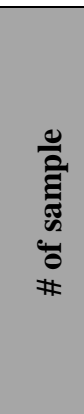 & 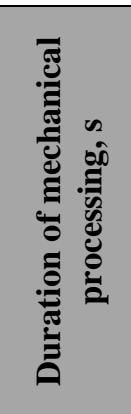 & 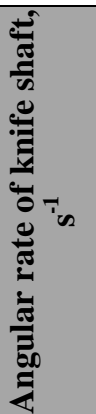 & 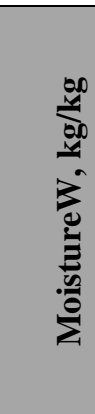 & 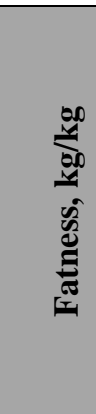 & 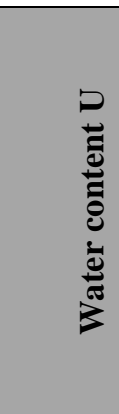 & 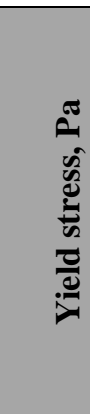 & 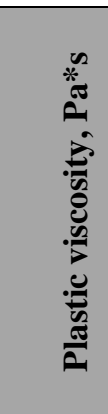 & 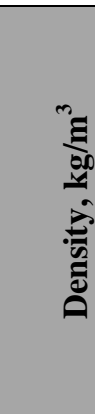 \\
\hline 1 & $\begin{array}{l}180 \\
360 \\
540 \\
720\end{array}$ & $\begin{array}{l}52.3 \\
- \\
- \\
- \\
\end{array}$ & $\begin{array}{l}0.770 \\
0.794 \\
0.793 \\
0.803\end{array}$ & $\begin{array}{l}0.102 \\
0.081 \\
0.086 \\
0.081\end{array}$ & $\begin{array}{l}3.344 \\
3.8614 \\
3.8286 \\
4.0906\end{array}$ & $\begin{array}{l}680 \\
750 \\
820 \\
840 \\
\end{array}$ & $\begin{array}{l}7.2 \\
6.85 \\
5.65 \\
5.9\end{array}$ & $\begin{array}{l}1083 \\
1071 \\
1066 \\
1058\end{array}$ \\
\hline 2 & $\begin{array}{l}180 \\
360 \\
540 \\
720\end{array}$ & $\begin{array}{l}167.5 \\
- \\
- \\
-\end{array}$ & $\begin{array}{l}0.758 \\
0.762 \\
0.783 \\
0.803\end{array}$ & $\begin{array}{l}0.101 \\
0.108 \\
0.096 \\
0.071\end{array}$ & $\begin{array}{l}3.1322 \\
3.1946 \\
3.6062 \\
4.0487\end{array}$ & $\begin{array}{l}640 \\
715 \\
815 \\
817\end{array}$ & $\begin{array}{l}7.14 \\
6.78 \\
5.57 \\
5.93\end{array}$ & $\begin{array}{l}1080 \\
1074 \\
1063 \\
1055\end{array}$ \\
\hline 3 & $\begin{array}{l}180 \\
360 \\
540 \\
720\end{array}$ & $\begin{array}{l}293 \\
- \\
- \\
-\end{array}$ & $\begin{array}{l}0.731 \\
0.753 \\
0.774 \\
0.763\end{array}$ & $\begin{array}{l}0.124 \\
0.110 \\
0.103 \\
0.104\end{array}$ & $\begin{array}{l}2.7188 \\
3.0469 \\
3.4209 \\
3.2158\end{array}$ & $\begin{array}{l}670 \\
760 \\
822 \\
840\end{array}$ & $\begin{array}{l}6.92 \\
6.22 \\
6.08 \\
5.89\end{array}$ & $\begin{array}{l}1076 \\
1071 \\
1067 \\
1053\end{array}$ \\
\hline 4 & $\begin{array}{l}180 \\
360 \\
540 \\
720\end{array}$ & $\begin{array}{l}418.7 \\
- \\
- \\
-\end{array}$ & $\begin{array}{l}0.713 \\
0.738 \\
0.762 \\
0.753\end{array}$ & $\begin{array}{l}0.122 \\
0.118 \\
0.108 \\
0.110\end{array}$ & $\begin{array}{l}2.488 \\
2.8139 \\
3.1946 \\
3.0429\end{array}$ & $\begin{array}{l}605 \\
670 \\
742 \\
740\end{array}$ & $\begin{array}{l}6.81 \\
6.16 \\
6.03 \\
5.82 \\
\end{array}$ & $\begin{array}{l}1071 \\
1066 \\
1059 \\
1048\end{array}$ \\
\hline
\end{tabular}

During the rotation of mixing screw, a negative pressure arises from its backside, the mass of minced meat is broken, forming cavities. An air phase bursts into the cavity under pressure. The moving forcemeat compresses the air, the temperature of the minced meat rises, the protein-lipoid shells of the fat particles are destroyed, and the particles are 
combined into larger ones. The union of fat particles is clearly seen in minced meat slices when conducting research during mechanical processing. On the other hand, on the back of the mixing screw accumulates a large amount of fat.

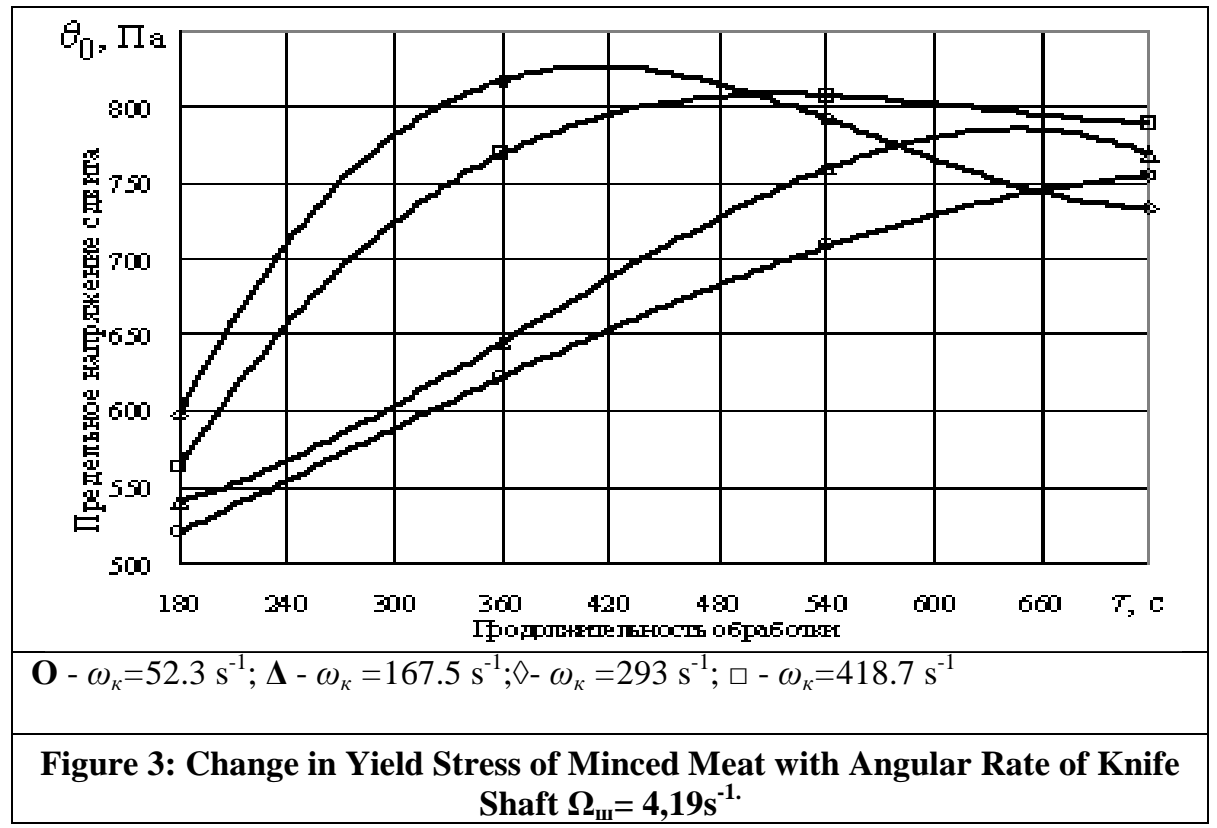

At this time of processing, the minced meat is saturated with highly dispersed air bubbles. When mixing screw contacted with minced meat, the fatty particles located at a short distance from one another collide with air bubbles. The protein shells partially detach from fat, moving to the surface of the air bubble. The fat particles gravitate towards the surface of the air bubble. The liquid fraction of fat on the surface of the air bubble provides the fusion of fat particles with the formation of small conglomerates. When the air bubble bursts, the original conglomerates are floated by other air bubbles and reintegrated into larger conglomerates. Aggregation of the fat fraction contributes to the formation of broth and fat edema during the heat treatment of sausages. During the mechanical processing of minced meat, colloid-chemical changes also occur. This contributes to a certain increase in temperature. 
Table 4: The Values of Yield Stress, Plastic Viscosity and Density of Minced Sausage at the Angular Rate of Mixing Screw 6.28 s'-1, Depending on Moisture, Fat, Water Content, Duration of Mechanical Processing and Angular Rate of a Knife Shaft

\begin{tabular}{|c|c|c|c|c|c|c|c|c|}
\hline 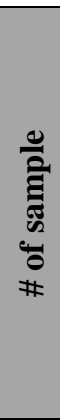 & 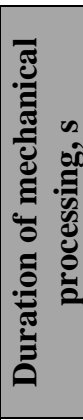 & 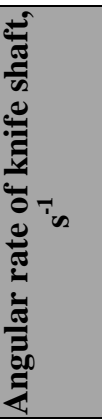 & 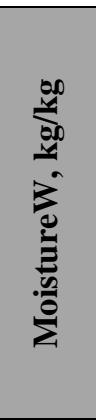 & 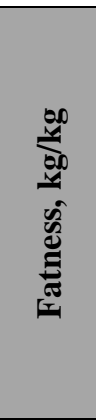 & 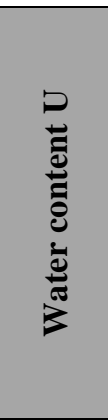 & 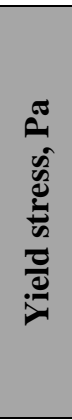 & 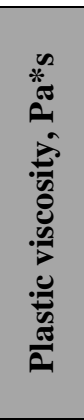 & 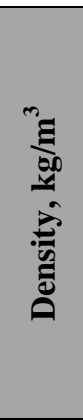 \\
\hline \multirow{4}{*}{1} & 180 & 52.3 & 0.770 & 0.102 & 3.344 & 650 & 7.3 & 1087 \\
\hline & 360 & - & 0.794 & 0.081 & 3.8614 & 720 & 6.3 & 1075 \\
\hline & 540 & - & 0.793 & 0.086 & 3.8286 & 735 & 5.8 & 1068 \\
\hline & 720 & - & 0.803 & 0.081 & 4.0906 & 820 & 6.55 & 1062 \\
\hline \multirow{4}{*}{2} & 180 & 167.5 & 0.758 & 0.101 & 3.1322 & 595 & 7.18 & 1084 \\
\hline & 360 & - & 0.762 & 0.108 & 3.1946 & 557 & 6.32 & 1077 \\
\hline & 540 & - & 0.783 & 0.096 & 3.6062 & 529 & 6.15 & 1069 \\
\hline & 720 & - & 0.803 & 0.071 & 4.0487 & 523 & 6.93 & 1060 \\
\hline \multirow{4}{*}{3} & 180 & 293 & 0.731 & 0.124 & 2.7188 & 570 & 6.91 & 1076 \\
\hline & 360 & - & 0.753 & 0.110 & 3.0469 & 560 & 6.25 & 1071 \\
\hline & 540 & - & 0.774 & 0.103 & 3.4209 & 522 & 6.12 & 1067 \\
\hline & 720 & - & 0.763 & 0.104 & 3.2158 & 540 & 6.77 & 1059 \\
\hline \multirow{4}{*}{4} & 180 & 418.7 & 0.713 & 0.122 & 2.488 & 505 & 6.80 & 1072 \\
\hline & 360 & - & 0.738 & 0.118 & 2.8139 & 570 & 6.12 & 1064 \\
\hline & 540 & - & 0.762 & 0.108 & 3.1946 & 542 & 6.06 & 1058 \\
\hline & 720 & - & 0.753 & 0.110 & 3.0429 & 560 & 6.72 & 1053 \\
\hline
\end{tabular}

The best quality characteristics of minced meat were observed when the yield stress value reached extreme values at the end of the second machining period at an angular rate of the blade shaft of 293 and $418.7 \mathrm{~s}^{-1}$.

The duration of mechanical processing, at which the physical-chemical and structural-mechanical properties of minced meat reached extreme values, depended on the degree of preliminary grinding in the meat grinder, the kinematic characteristics of the mincer and technological factors of minced meat (moisture, fat content). The lower the angular rate of the knife shaft and the mixing screw, the longer the machining time required to reach extreme values and vice versa.

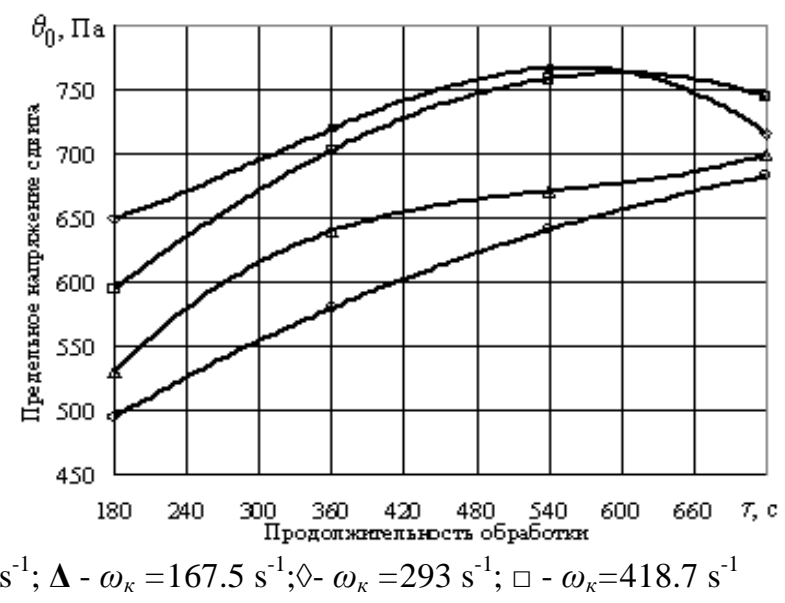

$\mathbf{O}-\omega_{\kappa}=52.3 \mathrm{~s}^{-1} ; \Delta-\omega_{\kappa}=167.5 \mathrm{~s}^{-1} ; \diamond-\omega_{\kappa}=293 \mathrm{~s}^{-1} ; \square-\omega_{\kappa}=418.7 \mathrm{~s}^{-1}$

Figure 4: Change in Yield Stress of Minced Meat with Angular Rate of Knife Shaft $\Omega_{\mathrm{II}}=6.28 \mathrm{~S}^{-1}$. 
Mechanical processing of minced meat for $720 \mathrm{~s}$ at angular velocity of the blade shaft of $52.3 \mathrm{~s}^{-1}$, increased the yield stress value of minced meat. After $720 \mathrm{~s}$ of processing, the yield stress slightly decreased and did not reach its extreme values. For minced meat processed for $540 \mathrm{~s}$ with an angular rate of the blade shaft 293 and $418.7 \mathrm{~s}^{-1}$, the yield stress reached extreme values. The shortest mechanical processing time was required for minced meat when the extreme values of yield stress were $410-420 \mathrm{~Pa}$.

Table 5: The Values of Yield Stress, Plastic Viscosity and Density of Minced Sausage at the Angular Rate of Mixing Screw 8.37 s-1, Depending on Moisture, Fat, Water Content, Duration of Mechanical Processing and Angular Rate of a Knife Shaft

\begin{tabular}{|c|c|c|c|c|c|c|c|c|}
\hline 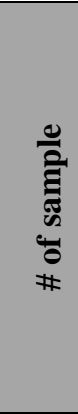 & 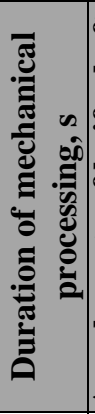 & 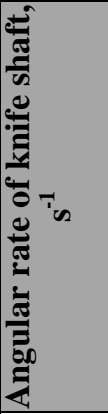 & 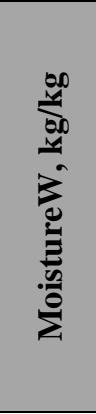 & 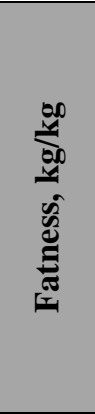 & 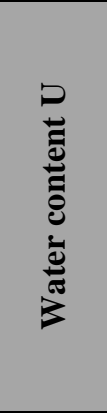 & 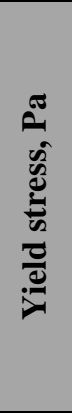 & 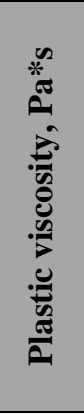 & 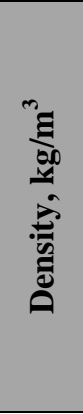 \\
\hline \multirow{4}{*}{1} & 180 & 52,3 & 0,770 & 0,102 & 3,344 & 660 & 7,35 & 1092 \\
\hline & 360 & - & 0,794 & 0,081 & 3,8614 & 725 & 6,4 & 1079 \\
\hline & 540 & - & 0,793 & 0,086 & 3,8286 & 815 & 6,15 & 1071 \\
\hline & 720 & - & 0,803 & 0,081 & 4,0906 & 825 & 7,1 & 1065 \\
\hline \multirow{4}{*}{2} & 180 & 167,5 & 0,758 & 0,101 & 3,1322 & 580 & 7,08 & 1089 \\
\hline & 360 & - & 0,762 & 0,108 & 3,1946 & 640 & 6,35 & 1076 \\
\hline & 540 & - & 0,783 & 0,096 & 3,6062 & 705 & 6,12 & 1068 \\
\hline & 720 & - & 0,803 & 0,071 & 4,0487 & 752 & 6,96 & 1062 \\
\hline \multirow{4}{*}{3} & 180 & 293 & 0,731 & 0,124 & 2,7188 & 550 & 6,89 & 1078 \\
\hline & 360 & - & 0,753 & 0,110 & 3,0469 & 615 & 6,27 & 1073 \\
\hline & 540 & - & 0,774 & 0,103 & 3,4209 & 675 & 6,11 & 1065 \\
\hline & 720 & - & 0,763 & 0,104 & 3,2158 & 595 & 6,76 & 1059 \\
\hline \multirow{4}{*}{4} & 180 & 418,7 & 0,713 & 0,122 & 2,488 & 510 & 6,82 & 1075 \\
\hline & 360 & - & 0,738 & 0,118 & 2,8139 & 560 & 6,16 & 1071 \\
\hline & 540 & - & 0,762 & 0,108 & 3,1946 & 535 & 6,08 & 1062 \\
\hline & 720 & - & 0,753 & 0,110 & 3,0429 & 490 & 6,71 & 1056 \\
\hline
\end{tabular}

The mathematical processing of experimental data was carried out according to the law of random variables. The results of the experiments and mathematical calculation revealed that the yield stress of minced meat depends on the modes of mechanical processing.

$\theta_{0}=497,47 \cdot \exp \left[6,1 \cdot 10^{-4} \cdot \frac{\tau}{\tau_{\text {pay }}} \cdot\left(0,14+\left(\frac{\omega_{\kappa}}{\omega_{u}}\right)^{0,052}\right)\right]$,

where $\omega_{k}, \omega_{u}$ - angular rate of knife shaft and mixing screw, $\mathrm{s}^{-1} ; \tau_{p a u}$ - efficient time of mechanical processing, $\mathrm{s}$. 


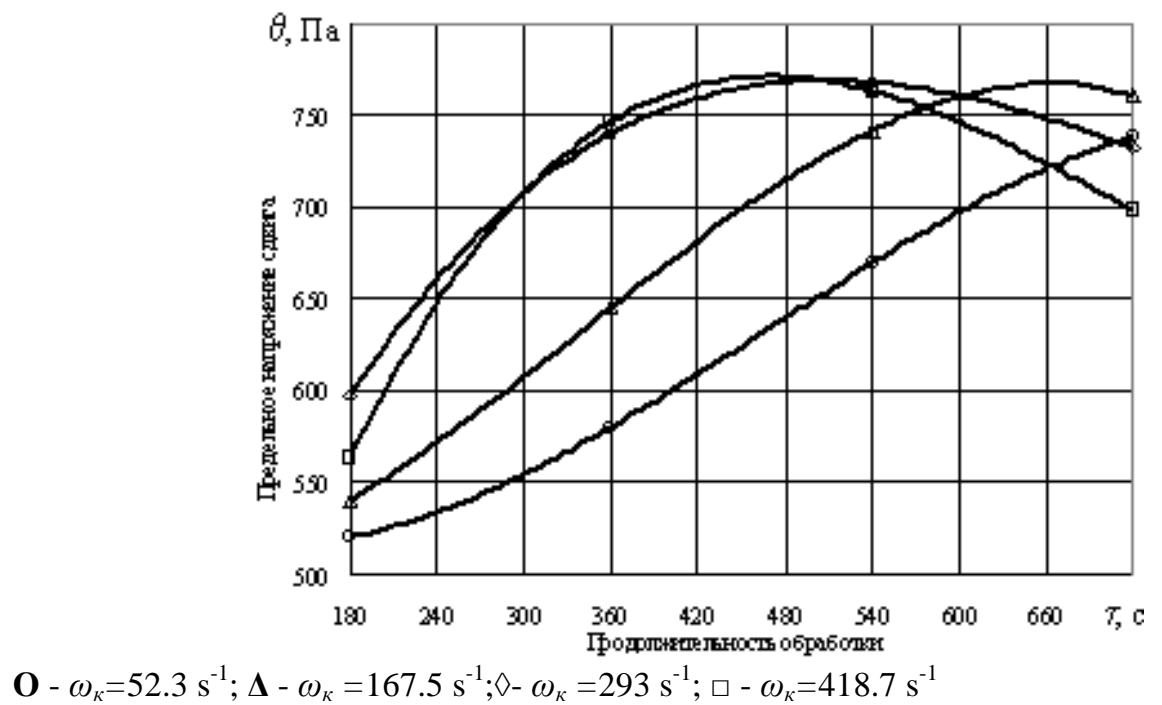

Figure 5: Change in yield stress of minced meat with angular rate of knife shaft $\omega_{\mathrm{III}}=8.37 \mathrm{~s}^{-1}$

The equation in the above form analytically describes the two main periods of mechanical processing of minced meat. The deviations of the yield stress values calculated by the equation and obtained experimentally, do not exceed $\pm 4.89 \%$.

The values of yield stress, calculated by the formula, turn out to be somewhat underestimated, than according to similar dependencies for sausage meat. This is explained by the fact that at present, according to the technological conditions for the preparation of minced meat, in order to save and better utilize raw materials, various additives are used to increase the nutritional value (protein stabilizer $-3-5 \%$, caseinate emulsion $-10 \%$, flour or starch $-45 \%$, hydrated protein - up to $10 \%$ in total, up to $17-20 \%$ ). These additives affect the creation of structure, reduce the values of yield stress and do not affect the nature of their changes in the process of mechanical processing.

\section{CONCLUSIONS}

The continuous growth in the production of meat products in the Republic of Kazakhstan necessitates the development of rational regimes for all production processes. Processes of fine grinding, mixing and forming of minced meat occupy the main place in the structure of the total production of sausages. Based on the obtained results, it was confirmed that mechanical processing of minced meat affects of the change of the yield stress at different time and the regimes of processing. Equations are proposed for calculating the extreme values of yield stress depending on the mechanical processing regime.

\section{REFERENCES}

1. Titova, Y. G., Arynova, Z. A., Kaidarova, L. K., Komarov, O. E. Development of the meat and dairy area of the procesing industry in the Republic of Kazakhstan under the modern conditions (2018) Journal of Applied Economic Sciences, 13 (1), pp. $207-215$.

2. Antipov S. T., Kretov I. T, Ostrikov A. N., Panfilov V. A., Urakov O. A. Machines and Apparatuses for Food Production. Moscow: "High School", -2001. -680 p.

3. Muratzhankyzy, N., Kassenov, A., Kakimov, M., Orynbekov, D., Moldabayeva, Z., Tokhtarov, Z., Yessimbekov, Z. Mathematical modeling of the relationship between separation and yield of meat-bone scraps in the pressing process (2018) International Journal of Mechanical Engineering and Technology, 9 (9), pp. 968-971. 
4. Solovyov, OV, Lisitsyn B. A. Improvement of durability of the cutting tool. Vsye o myase, 2005, 3: 33-35.

5. Kakimov, A., Suychinov, A., Mayorov, A., Yessimbekov, Z., Okuskhanova, E., Kuderinova, N., Bakiyeva, A. Meat-bone paste as an ingredient for meat batter, effect on physicochemical properties and amino acid composition (2017) Pakistan Journal of Nutrition, 16 (10), pp. 797-804.

6. Mustafayeva, A., Abdilova, G., Akimov, M., Yerengaliev, A., Muratzhankyzy, N., Okuskhanova, E. Change of yield stress of minced meat grinded with different kind of cutting mechanism (2016) Research Journal of Pharmaceutical, Biological and Chemical Sciences, 7 (5), pp. 498-504.

7. Kosoj, V. D., Malyshev, A. D., Judina, S. B. (2005) Engineering rheology in sausage production, p. 264.

8. Kakimov, A., Yessimbekov, Z., Bepeyeva, A., Kabulov, B., Kakimova, Z. Consistency cone penetrometry for food products (2015) Pakistan Journal of Nutrition, 14 (11), pp. 837-840.

9. Pelenko, V. V., Zuev, N. A., Olshevsky, R. G., Azaev, R. A., Shibanov, A. I., Kuzmin, V. V. (2008). Overview of foreign meat choppers and mixers for meat products. Scientific Journal NRU ITMO. Processes and Food Production Equipment, (1).

10. E. Tuleuov, A. Erengaliev, A. Kakimov, B. B. Kabulov The unit for the preparation of minced meat and molding sausages. Provisional patent number 13370 RK, MKI A 22 C 18/00, publ. September 15, 2003. Bul No. 9.

11. Kakimov A. K., Tuleuov E. T., Kabulov B. B. Combining the processes of fine grinding, mixing and molding stuffing in one unit. - Semipalatinsk: scientific journal "Vestnik SSU im. Shakarim ", № 3, 2003. - 35-36.

12. Lavrova L. P., V. V. Krylov. Sausage technology. - M.: Food industry, 1975.344 p.

13. Zinina, O., Merenkova, S., Soloveva, A., Savostina, T., Sayfulmulyukov, E., Lykasova, I., Mizhevikina, A. The effect of starter cultures on the qualitative indicators of dry fermented sausages made from poultry meat (2018) Agronomy Research, 16 (5), pp. 2265-2281.

14. Kakimov A. K., Tuleuov E. T., Kabulov, B. B. Development of methods for determining the characteristics of minced boiled sausages processed on the pilot mincer equipment. Food Technology and Service, 2003, 4:40-44 